Government will not easily be able to add extra duties as it likes unless it is prepared to pay for these. The effect of the Abortion Act and the likely effect of the Brodrick proposals 5 were cited as examples of how consultants' responsibilities could be unilaterally enlarged almost at a Parliamentary stroke. The contract, taken with a balanced expansion of consultant and training grades $^{6}$ (under the guidance of the Central Manpower Committee ${ }^{7}$ ), should ensure that patients get an improved service and, if the Review Body translates its hints of $1972^{8}$ into action, consultants a reward commensurate with their efforts.

Hospital doctors have been concerned not only with the nature of their contracts, but also with the level of N.H.S. authority that would be responsible for these contracts after 1974. They wanted contracts, except for those of house officers, to be held as now at regional level. 9 But the consultative document ${ }^{10}$ proposed that area health authorities should be the contracting body for all doctors in the N.H.S. A deputation from the B.M.A. and the Joint Consultants Committee recently met Sir Keith Joseph to argue the profession's case. Though no official announcement is expected before the White Paper on reorganization comes out this summer, Dr. Astley seemed confident enough to forecast at the Conference that the Secretary of State would accept the profession's "submissions to the extent that for consultants and senior registrars contracts will be at regional level for a trial period of five years," adding that for those in teaching hospitals contracts would be likely to be held at area level. If this is so, this will be a considerable success for the B.M.A.'s negotiators.

There was a flash of steel from the juniors on superannuation. Justifiably expressing annoyance over the lack of financial protection the N.H.S. scheme afforded to young doctors faced with the hazards of renal dialysis units and flying squad units, Mr. F. J. Bramble, Chairman of the Hospital Junior Staffs Group Council, condemned the Government for its dilatory approach. He warned that the juniors might be obliged to use the Industrial Relations Act to achieve a just solution if the Department of Health did not act quickly. With complaints on superannuation coming from all sides of the profession the juniors' warning is the first sign of tough political action and the Government should now have no doubts about the genuine sense of grievance among all N.H.S. doctors about superannuation.

One of the benefits of craft conferences is that it should free the A.R.M. to debate major intraprofessional issues. With only one day for their conference hospital doctors have less time than their general practitioner colleagues to discuss their own problems and the meeting gave the impression that they were still feeling their way in rather unfamiliar territory. However, brevity is no sin and with a short agenda and generally brief speeches the Conferenct had no difficulty in disposing of its business by tea time. Despite this swift progress the representatives, who included many juniors, dealt with some important issues apart from those already mentioned. Among these were the functions of the General Medical Council-an independent inquiry was called forproblems of hospital staffing, and study leave. The Conference, as well as giving the C.C.H.M.S. the urgent task of negotiating a new consultant contract so that it can be priced by the Review Body, has undoubtedly added strength to the B.M.A. in its dealings with the Government over superannuation and N.H.S. reorganization. It should also add authority to the Chairman of the C.C.H.M.S. when he speaks on behalf of hospital doctors at the forthcoming A.R.M.
1 British Medical fournal Supplement, 1971, 4, 73.

British Medical fournal, 1971, 4, 642.

British Medical fournal Supplement, 1966, 2, 153 British Medical fournal Supplement, 1966, 2, 171.

British Medical fournal Supplement, 1972, 2, 115.

6 British Medical Fournal Supplement, 1971, 3, 119

British Medical Fournal Supplement, 1971, 3, 120.

British Medical fournal Supplement, 1972, 3, 5.

9 British Medical fournal Supplement, 1970, 2, 113.

10 National Health Service Reorganisation: Consultative Document. London, H.M.S.O., 1971.

\section{Streptococcal Sore Throat}

That group A haemolytic streptococci cause sore throat is a dictum familiar to generations of medical students. They were also taught that the diagnosis should be confirmed by throat swab and that penicillin treatment was both efficacious and necessary to prevent the dangerous complication of rheumatic fever.

Such teaching has had to defend its respectability in the face of some serious setbacks. To highlight a few: haemolytic streptococci are not recoverable from most patients with acute sore throat, ${ }^{1}$ and, when they are not, all belong to group A. ${ }^{2}$ Group A streptococci are commonly found in the throat despite lack of symptoms, but their presence there may nevertheless be associated with a rise of streptococcal antibody, ${ }^{3}$ so that it can be difficult to distinguish between patient and carrier. ${ }^{4}$ Despite the high-and continuing - sensitivity of haemolytic streptococci to penicillin, this antibiotic fails to exert a particularly dramatic effect on the clinical illness. W. Brumfitt and J. D. H. Slater ${ }^{5}$ found that after three days $50 \%$ of patients treated with penicillin still had sore throats as against $70 \%$ of those receiving non-specific treatment. After five days the figures were $10 \%$ and $20 \%$ respectively. Treatment of acute sore throat may not appreciably affect the chance of developing acute rheumatism, 6 which in the absence of a family history, previous rheumatism, or epidemic streptococcal infection is small.

P. W. Ross has delivered two more blows to the traditionalists. In his study, ${ }^{7}$ throat swabs showed the presence of haemolytic streptococci in only two-thirds of infected patients. Furthermore, nearly $25 \%$ of children treated with oral penicillin still had streptococci in the throat on the fifth day of treatment. ${ }^{8}$ The traditional throat swabbing is such an inefficient technique that it both underestimates the frequency with which haemolytic streptococci are associated with acute sore throat and overestimates the efficacy of penicillin therapy. Ross had much more success with the culture of saliva than he had with throat swabs, showing that as a group symptomatic patients harboured many more organisms than did symptomless "carriers."

Despite the massive effort devoted to the study of streptococcal infection, particularly in America, the last word has yet to be written on the utility of swabbing sore throats and giving the patients penicillin. But in the meantime doctors should critically examine their traditional approach to this common affliction.

1 Stillerman, M., and Bernstein, S. H., American fournal of Diseases in Childhood, 1961, 101, 476.

2 Quinn, R. W., and Lowry, P. N., Yale fournal of Biology and Medicine, $1970,43,1$.

${ }^{3}$ Honikman, L. H., and Massell, B. F., Pediatrics, 1971, 48, 573.

4 Bisno, A. L., Pearce, I. A., Wall, H. P., Moody, M. D., and Stollerman, G. H., New England fournal of Medicine, 1970, 283, 561 .

5 Brumfitt, W., and Slater, J. D. H., Lancet, 1957, 1, 8 .

- Weinstein, L., Boyer, N. H., and Goldfield, M., New England fournal of Medicine, 1955, 253, 1

7 Ross, P. W., fournal of Hygiene, 1971, 69, 347.

${ }^{8}$ Ross, P. W., Fournal of Hygiene, 1971, 69, 355. 